\title{
ANTIMICROBIAL ACTIVITIES AND PHYTOCHEMICAL INVESTIGATION OF FERN, LYGODIUM FLEXUOSUM (LINN) SW.
}

\author{
Jeeshna, M.V. \\ Department of Botany, Sree Narayana College, Kannur, Kerala-670 009. \\ E-mail: mvjeeshna@gmail.com
}

\begin{abstract}
The present study revealed the presence of many medicinally active constituent in Lygodium flexuosum, suggesting that this species have potential to synthesize useful secondary metabolites. In this studies two different types (vegetative material and sporophyll bearing type) of this species showed the presence of secondary metabolites such as alkaloids, flavonoids, saponins, tannins, phenols and glycosides. In which vegetative material showed the presence of all secondary metabolites. The low polar solvent extracts such as petroleum ether and acetone showed minimum presence of secondary metabolites. The antibacterial studies revealed that methanol extracts of sporophyll type exhibited significant activity $(8.5 \mathrm{~mm})$ against the bacterium, Klebsiella pneumonia. The next antibacterial activity showed by chloroform extracts of sporophyll type against the same bacteria $(8.2 \mathrm{~mm})$. In antifungal studies, methanol extracts of vegetative material has the highest inhibitory activity $(19.3 \mathrm{~mm})$ against the fungus Cladosporium sp. Next higher fungal activity was showed by same extract of sporophyll type against the fungus Rhizopus sp. (16.08 mm). The study confirms the antimicrobial potential of Lygodium flexuosum extracted using various solvents.
\end{abstract}

Keywords: Secondary metabolites, potential, phytochemical analysis, antimicrobial.

\section{INTRODUCTION}

Plants have been used for the treatment of diseases all over the world before the advent of modern clinical drugs. Humans have been dependent upon the plants as an important source of medicine since ancient times. Very small portion of Indian medicinal plants belongs to lower groups. Medicinal value of the ferns have been known to man for more than 2000 years, they have been found with very little application in modern chemotherapy as compared to the angiosperms. In India, total fern species were 1022 , they have been recorded with respect to vast angiospermic diversity (15000 species) in that ferns plants played a significant role in ethno-medicine. In ancient Indian medicine several ferns were used, and in particular by Unani physicians in India and Western Asia. Reports showed that ferns were used by the people of India and in various other countries. Most of the diseases against which the lycophytes are said to have curative properties, are caused by bacteria (grampositive, gram- negative or acid-fast). A systematic survey of the antibiotic activity of the ferns, however, has been scarcely undertaken (Banerjee and Sen, 1980). In most cases the antimicrobial activities of few ferns were being screened.

The screening of plant extracts of pteridophytes has been of great interest to scientists for the discovery of new drugs effective in the treatment of several diseases. Lygodium flexuosum (Lygodinaceae) is an epiphytic plant which is medicinally very important. The rhizome and root is useful in the treatment of jaundice. Leaf extract had antiproliferative and apoptotic activity in cancer cells. This fern is reported to exhibit antiferility activity. Extract of rhizome of is used to cure gonorrhoea. The ash of the plant is used for treating herps. This plant is also used to feed domestic animals to treat foot and mouth diseases (Wills and Asha, 2006a and 2006b). In this study an attempt was made to analyse the preliminary phytochemistry and antimicrobial activities of Lygodium flexuosum (vegetative material and sporophyll type).

\section{MATERIALS AND METHODS}

\subsection{Collection of plant materials}

For the present study of phytochemical analysis, powdered material of whole plant was used. The clean and healthy individuals of vegetative material and sporophyll bearing types were collected from in an around the Sree Narayana College, Kannur and they were shade dried separately. 


\subsection{Preparation of plant extracts}

To know the presence of major phytochemicals, the shade dried plants of two different types individuals (vegetative material and sporophyll bearing) were made into a fine powder of 40 mesh size using the pulverizer separately. Following that, $100 \mathrm{~g}$ of the powder was weighed and successively extracted using $150 \mathrm{ml}$ solvents viz. petroleum ether, acetone, chloroform and finally with methanol using the rotary shaker for 10 days (Gafner et al., 1985). The extract was filtered through Whatman No.1 filter paper to remove all undissolved matter, including cellular materials and other constituents that are insoluble in the extraction solvents.

\subsection{Preliminary phytochemical analysis}

Preliminary phytochemical testing for the presence of various compounds were analysed by using standard method of procedure.

\subsubsection{Test for alkaloids (Ciulci, 1994)}

To $1 \mathrm{ml}$ of each extract in two separate test tubes, 2-3 drops of Dragendorff's and Meyer's reagents were separately added. An orange red precipitate/turbidity with Dragendorff's reagent or white precipitate with Meyer's reagent would indicate the presence of alkaloids.

\subsubsection{Test for flavonoids (Sofowara, 1993)}

To $4 \mathrm{ml}$ of each of the extracts, a piece of magnesium ribbon was added followed by concentrated $\mathrm{HCl}$ drop wise. A colour ranging from crimson to magenta indicated the presence of flavonoids.

\subsubsection{Test for glycosides (Gokhale, et al., 2008)}

Keller Kiliani test: To the $2 \mathrm{ml}$ of extracts, $1 \mathrm{ml}$ of glacial acetic acid with ferric chloride and concentrated sulphuric acid is added. The appearance of blue colour indicates the presence of glycosides.

\subsubsection{Test for saponins (Brain and Turner, 1975)}

One $\mathrm{ml}$ of extract was taken in a test tube and $5 \mathrm{ml}$ of distilled water was added and vigorously shaken. A persistent froth that lasted for at least 15 minutes indicated the presence of saponins.

\subsubsection{Test for tannins (Mace an} Ciulci, 1994)

Two $\mathrm{ml}$ of the extracts were diluted with distilled water in separate test tubes and 2-3 drops of $5 \%$ ferric chloride $\left(\mathrm{Fecl}_{3}\right)$ solution was added. A green-black or blue-black colouration indicated the presence of tannins.

\subsubsection{Test for phenols (Krishnamoorthy, 1988)}

Five $\mathrm{ml}$ of the concentrated extracts were taken and $2 \mathrm{ml}$ of neutral ferric chloride solution was added. Appearance of violet colour indicates the presence of phenols.

\subsection{Antimicrobial studies}

For antimicrobial studies, three bacterial strains viz., Escherichia coli , Klebsiella pneumonia and Proteus mirabilis and four fungal strains viz., Aspergillus flavus, Penicillium sp., Cladosporium sp., and Rhizopus sp. were used which have been obtained from the Department of Microbiology, Sree Narayana College, Kannur. The above mentioned bacterial and fungal strains were grown in nutrient agar medium and potato dextrose agar medium respectively. The different extracts of three different species were tested for antimicrobial activity by following disc diffusion method (Bauer et al., 1966). The antibiotic disc tetracycline $(30 \mu \mathrm{g})$ was taken as positive control. Triplicates were maintained for all extracts of three species. The antimicrobial assay plates were incubated at $37^{\circ} \mathrm{C}$ for $24 \mathrm{~h}$. The diameters of the inhibition zones were measured.

\section{RESULTS}

Plants are recognized for their ability to produce a wealth of secondary metabolites, extensively used for traditional medicine for centuries to treat a variety of disease. Secondary metabolites in plant products are responsible for several biological activities in living systems. Antimicrobial properties of several plant extracts have been attributed due to the secondary metabolites (Jaiganesh and Arunachalamb, 2011). Pharmaceutical and scientific communities have recently received the attention of the medicinal plants, and various publications have documented the therapeutic worth of natural compounds to validate the claims of their biological activity (Bauer et al., 1966).

Table 1. Result of preliminary phytochemical analysis of Lygodium flexuosum (vegetative material).

\begin{tabular}{|c|c|c|c|c|c|c|}
\hline \multirow[b]{2}{*}{$\begin{array}{l}\text { Extr } \\
\text { act }\end{array}$} & \multicolumn{6}{|c|}{ Secondary metabolites } \\
\hline & $\begin{array}{c}\text { Alkalo } \\
\text { ids }\end{array}$ & $\begin{array}{c}\text { Flavon } \\
\text { oids }\end{array}$ & $\begin{array}{c}\text { Glycosi } \\
\text { des }\end{array}$ & $\begin{array}{c}\text { Sapon } \\
\text { ins }\end{array}$ & $\begin{array}{c}\text { Tann } \\
\text { ins }\end{array}$ & $\begin{array}{c}\text { Phen } \\
\text { ols }\end{array}$ \\
\hline $\mathrm{P}$ & + & - & + & - & + & - \\
\hline A & + & - & ++ & + & ++ & - \\
\hline $\mathrm{C}$ & - & - & +++ & - & + & - \\
\hline M & + & ++ & + & + & + & ++ \\
\hline
\end{tabular}


In the present study of preliminary phytochemical analysis, the crude extracts of whole plant body of Lygodium flexuosum showed diverse phytoprofiles with reference to different solvents. The results of phytochemical analysis of vegetative material and sporophyll types of the plant species are represented in Table 1 and 2. Among the four solvents used methanol extract showed the presence of secondary metabolites such as alkaloids, saponins, tannins, phenols, glycosides and flavonoids. While comparing the results of the preliminary phytochemical analysis, vegetative material of the species showed presence all the secondary metabolites.

Table 2. Result of preliminary phytochemical analysis of Lygodium flexuosum (sporophyll).

\begin{tabular}{|c|c|c|c|c|c|c|}
\hline \multirow[b]{2}{*}{$\begin{array}{l}\text { Extr } \\
\text { acts }\end{array}$} & \multicolumn{6}{|c|}{ Secondary metabolites } \\
\hline & $\begin{array}{c}\text { Alkal } \\
\text { oids }\end{array}$ & $\begin{array}{l}\text { Flavo } \\
\text { noids }\end{array}$ & $\begin{array}{l}\text { Glyco } \\
\text { sides }\end{array}$ & $\begin{array}{l}\text { Sapo } \\
\text { nins }\end{array}$ & $\begin{array}{l}\text { Tan } \\
\text { nins }\end{array}$ & $\begin{array}{c}\text { Phe } \\
\text { nol }\end{array}$ \\
\hline $\mathrm{P}$ & + & - & ++ & - & + & - \\
\hline $\mathrm{A}$ & + & - & + & + & +++ & - \\
\hline $\mathrm{C}$ & - & - & ++ & - & +++ & - \\
\hline M & ++ & ++ & + & + & +++ & - \\
\hline
\end{tabular}

In the two study material of the species, alkaloids shows its presence in petroleum ether, acetone and methanol. In which maximum presence was shown by methanol extract of sporophyll type. Flavonoid compounds are present in methanol extracts of two different types. In all other low polar solvents this secondary metabolite is absent. Glycosides are present in almost all extracts of two different types this species. In which chloroform extracts shows maximum content of glycosides. Saponins are represented by acetone and methanol extracts of vegetative material and sporophyll types at its minimum level. In all other extracts they are absent. Tannins are represented almost all extracts of two different types of this species. In which the sporophyll type shows maximum result in acetone, choloroform and methanol extracts. Phenols showed their presence only in the vegetative material of methanol extracts. In sporophyll type, this compound is completely absent.

The antibacterial activity of Lygodium flexuosum were assayed invitro by agar disc diffusion method against three bacterial species (Table 3 ). The result of the study reveals that methanol extract of sporophyll type exhibited significant activity (8.5 $\mathrm{mm}$ ) against the bacterium Klebsiella pneumonia. The next higher bacterial activity is showed by chloroform extract of sporophyll type against the bacterium Klebsiella pneumonia $(8.2 \mathrm{~mm})$. On the other hand acetone extract of vegetative material showed very less activity against the bacteria Klebsiella pneumonia $(5.0 \mathrm{~mm})$.

Table 3. Antimicrobial activity of plant extracts of Lygodium flexuosum (vegetative material).

\begin{tabular}{|c|c|c|c|c|c|c|c|c|}
\hline \multirow{3}{*}{$\begin{array}{c}\text { Plant } \\
\text { extract }\end{array}$} & \multirow[b]{3}{*}{ Concentration } & \multicolumn{7}{|c|}{ Diameter of inhibition zone(mm) } \\
\hline & & \multicolumn{3}{|c|}{ Bacteria } & \multicolumn{4}{|c|}{$\begin{array}{r}\text { Fungi } \\
\end{array}$} \\
\hline & & $\begin{array}{c}\text { Escherichia } \\
\text { coli }\end{array}$ & $\begin{array}{c}\text { Klebsiella } \\
\text { pneumonia }\end{array}$ & $\begin{array}{l}\text { Proteus } \\
\text { mirabilis }\end{array}$ & $\begin{array}{l}\text { Aspergillus } \\
\quad \text { flavus }\end{array}$ & $\begin{array}{l}\text { Penicillium } \\
\text { sp. }\end{array}$ & $\begin{array}{c}\text { Cladosporium } \\
\text { sp. }\end{array}$ & $\begin{array}{c}\text { Rhizopus } \\
\text { sp. }\end{array}$ \\
\hline \multirow{4}{*}{$\begin{array}{l}\text { Petroleum } \\
\text { ether } \\
\text { Acetone }\end{array}$} & $\mathrm{C}^{*}$ & $6.0 \pm 0.10$ & $6.0 \pm 0.10$ & $6.0 \pm 0.10$ & $6.1 \pm 0.08$ & $6.5 \pm 0.08$ & $6.0 \pm 0.01$ & $6.1 \pm 0.08$ \\
\hline & 100 & $5.2 \pm 0.02$ & $5.1 \pm 0.04$ & $5.1 \pm 0.01$ & $5.5 \pm 0.06$ & $5.12 \pm 0.07$ & $5.2 \pm 0.01$ & $10.12 \pm 0.07$ \\
\hline & & $6.1 \pm 0.2$ & $6.0 \pm 0.10$ & $6.0 \pm 0.10$ & $6.0 \pm 0.10$ & $7.3 \pm 0.11$ & $7.5 \pm 0.06$ & $6.08 \pm 0.12$ \\
\hline & 100 & $5.1 \pm 0.2$ & $5.0 \pm 0.2$ & $5.12 \pm 0.07$ & $7.13 \pm 0.01$ & $12.0 \pm 0.17$ & $7.06 \pm 0.04$ & $16.06 \pm 0.24$ \\
\hline \multirow[t]{2}{*}{ Chloroform } & & $6.01 \pm 0.2$ & $6.0 \pm 0.10$ & $6.03 \pm 0.2$ & $6.1 \pm 0.5$ & $7.06 \pm 0.08$ & $7.56 \pm 0.02$ & $6.09 \pm 0.55$ \\
\hline & 100 & $5.3 \pm 0.02$ & $5.2 \pm 0.02$ & $5.1 \pm 0.02$ & $5.31 \pm 0.02$ & $8.16 \pm 0.03$ & $7.3 \pm 0.06$ & $11.56 \pm 0.04$ \\
\hline \multirow[t]{2}{*}{ Methanol } & 4 & $6.01 \pm 0.2$ & $6.0 \pm 0.10$ & $10.2 \pm 0.04$ & $7.16 \pm 0.04$ & $7.46 \pm 0.34$ & $7.10 \pm 0.01$ & $7.2 \pm 0.11$ \\
\hline & 100 & $5.3 \pm 0.02$ & $5.1 \pm 0.10$ & $7.12 \pm 0.06$ & $5.13 \pm 0.02$ & $11.06 \pm 0.04$ & $19.3 \pm 0.06$ & $12.06 \pm 0.04$ \\
\hline
\end{tabular}

Table 4. Antimicrobial activity of plant extracts of Lygodium flexuosum (sporophyll).

\begin{tabular}{|c|c|c|c|c|c|c|c|c|}
\hline \multirow{3}{*}{$\begin{array}{c}\text { Plant } \\
\text { extract }\end{array}$} & \multirow[b]{3}{*}{ Concentration } & \multicolumn{7}{|c|}{ Diameter of inhibition zone(mm) } \\
\hline & & \multicolumn{3}{|c|}{ Bacteria } & \multicolumn{4}{|c|}{ Fungi } \\
\hline & & $\begin{array}{c}\text { Escherichia } \\
\text { coli }\end{array}$ & $\begin{array}{c}\text { Klebsiella } \\
\text { pneumonia }\end{array}$ & $\begin{array}{l}\text { Proteus } \\
\text { mirabilis }\end{array}$ & $\begin{array}{l}\text { Aspergillus } \\
\text { flavus }\end{array}$ & $\begin{array}{l}\text { Penicillium } \\
\text { sp. }\end{array}$ & $\begin{array}{c}\text { Cladosporium } \\
\text { sp. }\end{array}$ & $\begin{array}{c}\text { Rhizopus } \\
\text { sp. }\end{array}$ \\
\hline \multirow{4}{*}{$\begin{array}{l}\text { Petroleum } \\
\text { ether } \\
\text { Acetone }\end{array}$} & $\mathrm{C}^{*}$ & $6.05 \pm 0.11$ & $6.02 \pm 0.50$ & $6.12 \pm 0.13$ & $6.2 \pm 0.08$ & $6.5 \pm 0.08$ & $6.6 \pm 0.15$ & $6.1 \pm 0.08$ \\
\hline & 100 & $5.12 \pm 0.02$ & $5.15 \pm 0.04$ & $5.10 \pm 0.04$ & $5.5 \pm 0.06$ & $5.11 \pm 0.17$ & $5.2 \pm 0.11$ & $7.12 \pm 0.07$ \\
\hline & $u$ & $6.1 \pm 0.17$ & $6.4 \pm 0.8$ & $6.0 \pm 0.14$ & $6.0 \pm 0.18$ & $7.13 \pm 0.09$ & $7.5 \pm 0.55$ & $6.38 \pm 0.17$ \\
\hline & 100 & $7.15 \pm 0.2$ & $6.0 \pm 0.23$ & $6.12 \pm 0.08$ & $5.43 \pm 0.01$ & $10.07 \pm 0.65$ & $10.06 \pm 0.04$ & $6.06 \pm 0.2$ \\
\hline \multirow[t]{2}{*}{ Chloroform } & & $6.11 \pm 0.12$ & $6.47 \pm 0.07$ & $6.8 \pm 0.22$ & $6.6 \pm 0.5$ & $7.96 \pm 0.18$ & $7.50 \pm 0.08$ & $6.30 \pm 0.51$ \\
\hline & 100 & $7.13 \pm 0.02$ & $8.20 \pm 0.22$ & $6.61 \pm 0.02$ & $5.33 \pm 0.22$ & $6.16 \pm 0.33$ & $9.30 \pm 0.05$ & $14.56 \pm 0.12$ \\
\hline \multirow{2}{*}{ Methanol } & & $6.11 \pm 0.21$ & $6.4 \pm 0.33$ & $10.2 \pm 0.51$ & $7.11 \pm 0.14$ & $7.16 \pm 0.74$ & $7.18 \pm 0.11$ & $7.22 \pm 0.13$ \\
\hline & 100 & $6.3 \pm 0.22$ & $8.5 \pm 0.16$ & $7.10 \pm 0.08$ & $5.33 \pm 0.22$ & $12.56 \pm 0.05$ & $15.3 \pm 0.56$ & $16.08 \pm 0.44$ \\
\hline
\end{tabular}


The antifungal activities of four different extracts of Lygodium flexuosum against four fungal strains are given in the Table 4 (Fig. 3). The result of the studies states that methanol extract of vegetative material has the highest inhibitory activity (19.3 $\mathrm{mm}$ ) against the fungus Cladosporium sp. Next higher fungal activity was shown by methanol extract of sporophyll type against the Rhizopus sp. (16.08 mm). On the other hand petroleum ether extract of both the type shows very less activity against the fungus Cladosporium sp. (5.2 $\mathrm{mm})$.

\section{DISCUSSION}

The tribal communities, ethnic groups and folklore throughout the world are utilizing pteridophyte plant parts like rhizome, stem, fronds, pinnae and spores in various ways for the treatment of ailments since ancient time (Kumar and Kushik, 1999). The medicinal value is caused by presence of chemical compounds in ferns. Hence this study is focused to analyse the compounds which are present in our study plant species, Lygodium flexuosum with four different solvent extracts. Maximum number of compounds were screened in methanol extract. Alkaloids and flavonoids are considered as the source of antimicrobial activity. In this research work alkaloids are present in all most all extracts but flavonoids are present only in methanol extract. Tannins are also represent in almost all extracts of two different type of this species which have potential value as cytotoxic agent (Aguinaldo et al., 2005). So this plant can be used as an anticancer agent. Phenolic compounds are important source of antimicrobial and insecticidal activities. But phenol showed their presence only in the methanol extracts of vegetative material of this species. Saponins and glycosides has been implicated as bioactive antibacterial agents (Mandal et al., 2005). Saponins are represented by acetone and methanol extract of two different types at its minimum level. Glycosides are present in almost all extract of two different types of this species. Glycosides are considered as a class of molecules which play crucial roles in combating a number of dreadful diseases especially heart diseases. Thus our study also leads to the further research in the way of isolation and identification of active compounds.

In the present investigation, in vitro antimicrobial efficiency of two types of Lygodium flexuosum, was quantitatively assessed on the basis of zone of inhibition. In this two different types studied the present investigation exhibited varying degree of inhibitory effect against the selected microbial pathogens. Eloff (1998) reported that methanol was the most effective solvent for plant extraction than chloroform, acetone and petroleum ether. Our studies confirmed the Eloff observation with maximum activity. The present study indicates antimicrobial property of the plant against the selected strains of pathogenic microbes varies depends upon the solvent medium used for extraction.

The inhibitory activity was higher for the extracts of high polar solvent like methanol. It may be attributed to higher polarity of the solvents which naturally have high degree of extracting capacity (Aiyelaagbe et al., 2007). Raskin et al. (2002) pointed out that more than one compound in the crude extract might result in improved efficiency due to their synergetic effect.

\section{CONCLUSION}

The results obtained in this plant concluded that the antimicrobial property plays an important role in the identification of therapeutically potent bioactive compounds. This exploration on plant-derived antimicrobials was carried out to determine the identification of antimicrobial compounds within this plant and also to determine their full spectrum of efficacy.

\section{ACKNOWLEDGEMENT}

The author is thankful to Kerala State Council for Science, Technology and Environment for providing financial support to carry out this project.

\section{REFERENCES}

Aguinaldo AM, Espeso EI, Guevara BQ, Nonato MG (2005). Phytochemistry. In: Guevara BQ. (ed.) A guidebook to plant screening: phytochemical and biological. Manila: University of Santo Tomas. pp. 121-125.

Aiyelaagbe 00, Adeniyi BA, Fatunsin OF, Arimah BD (2007). In vitro antimicrobial activity and photochemical analysis of Jatropha curcas roots. Intern. J. Pharmacol. 3(1): 106-110.

Banerjee RD Sen SP (1980). Antibiotic activity of pteridophytes. Ecol. Bot. 34(3):284-298.

Bauer RW Kirby MDK, Sherris JC, Turck M (1966). Antibiotic susceptibility testing by standard single disc diffusion method. Am. J. Clin. Pathol. 45: 493-496.

Brain KR, Turner TD (1975). The Practical Evaluation of Phytopharmaceuticals. Wright Scientechica, Bristol pp.57-58. 
Ciulci I (1994). Methodology for the analysis of vegetable drugs. Chemical industries Branch, Division of Industrial Operations. UNIDO, Romania. 24:26 - 67.

Eloff JN (1998). Which extractant should be used for the screening and isolation of antimicrobial components from plants? J.Ethanopharmacol.60:1-8.

Gafner F, Msonthi JD, Hostettmann K (1985). Molluscicidal saponins from Talinum tenuissimum Dinter. Helvet Chim. Acta. 68: 555558.

Gokhale SB, Kokate CK, Purohit AP (2008). A text book of pharmacognosy. Nirali Prakashan, Maharashtra, India pp: 889.

Jaiganesh KP, Arunachalamb G.(2011). Preliminary phytochemical screening and antimicrobial potential of Pterospermum canescens roxb, (Sterculiaceae). Int J Pharm Sci ;3:139-41.

Kumar A, Kushik P (1999). Antibacterial effect of Adiantum capillus-veneris Linn. Indian Fern J. 16: $72-74$.
Mace, Gorbach SL (1963). Anaerobic bacteriology for clinical laboraties pharmacognosy. 23: 89-91.

Mandal P, Sinha Babu SP, Mandal NC (2005). Antimicrobial activity of saponins from Acacia auriculiformis. Fitoterapia. 76(5): 462-565.

Raskin IDM, Ribnicky S, Komarnitsky N llic, Poulev A, Borijuk JN, Brinker A, Morenis DA, Ripol C, Yakobi N, Neal JMO, Cornvell T, Pastor I, Fridlender B (2002). Plants and Human Health in the twenty-first century. Trends Biotechnol. 20:522-53.

Sofowara AA (1993). Medicinal plants and Traditional Medicines in Africa. Spectrum Books Ltd., Ibadan, Nigeria. 2: 81-85.

Wills PJ and VV Asha (2006a). Protective effect of Lygodium flexuosum (L.)SW. (Lygodiacae) against D-galactosamine induced liver injury in rats. J Ethnopharmacol. 108: 116-23.

Wills PJ and VV Asha (2006b). Protective effect of Lygodium flexuosum (L.)Sw. extract against carbon tetrachloride -indused acute liver injury in rats.J Ethnopharamacol. 108:3 20-6. 